\title{
The post-politics of the green economy in Turkey: re-claiming the future?
}

\author{
Ethemcan Turhan ${ }^{\mathrm{a} 1}$ \\ Arif Cem Gündoğan ${ }^{b}$ \\ ${ }^{a}$ KTH Royal Institute of Technology, Stockholm, Sweden \\ ${ }^{\mathrm{b}}$ Middle East Technical University, Ankara, Turkey
}

\begin{abstract}
The green economy is often defined as an economic configuration that results in improved human wellbeing and social equity, while reducing (or at least decoupling from) environmental risks. It is elusive, and can be read as a new way of ensuring and maintaining capital accumulation accompanied by neoliberal austerity policies, where a green rationale is required to maintain the structural roots of the global political economy. As such, critics often identify its self-contradictory nature, in giving legitimacy and coherence to a number of public policies. This article critically examines the post-politicisation of the green economy, by tracing its social construction and meaning-making. In doing so, it follows the green economy debate in the post-politicization of the environment in Turkey, a rapidly developing country with significant socio-ecological challenges. The analysis suggests that the green economy will become more important at Turkey tries to meet international environmental agreements. The article sheds light on its preparatory report for the Rio+20 Summit, titled Turkey's sustainable development report: claiming the future 2012. We find that the green economy serves as a useful discursive tool to legitimize a statefacilitated, market-driven, full-frontal assault on ecosystems in Turkey, particularly in the energy sector. We argue that a clear rejection of such framings and the development of alternatives to postpoliticization, are the two key challenges facing the environmental movement in the country.
\end{abstract}

Key Words: green economy, Turkey

\section{Résumé}

L'économie verte est souvent définie comme une configuration économique qui améliore le bien-être humain et l'équité sociale, tout en réduisant (ou du moins découplant) les risques environnementaux. Elle est insaisissable et peut être lue comme une nouvelle façon d'assurer et de maintenir l'accumulation de capital, accompagnée de politiques d'austérité néolibérales, où si une justification verte est nécessaire pour maintenir les racines structurelles de l'économie politique mondiale. En tant que tels, les critiques identifient souvent sa nature contradictoire, en donnant la légitimité et la cohérence à un certain nombre de politiques publiques. Cet article examine de manière critique la post-politisation de l'économie verte, en retraçant sa construction sociale et sa signification. Ce faisant, elle fait suite au débat sur l'économie verte dans la post-politisation de l'environnement en Turquie, un pays en développement rapide avec des défis socio-écologiques importants. Nous pensons que l'économie verte deviendra plus importante à mesure que la Turquie tentera de respecter les accords internationaux sur l'environnement. L'article fait la lumière sur son rapport préparatoire pour le Sommet Rio + 20, intitulé Rapport sur le développement durable de la Turquie: prétendre à l'avenir 2012. Nous constatons que l'économie verte sert d'instrument discursif utile pour légitimer un assaut frontal sur les écosystèmes en Turquie, en particulier dans le secteur de l'énergie. Il est facilité par l'État et axé sur le marché. Nous soutenons que le rejet évident de ces cadrages - et le

\footnotetext{
${ }^{1}$ Dr. Ethemcan Turhan, postdoctoral researcher, Environmental Humanities Lab, KTH Royal Institute of Technology, Stockholm, Sweden. Email: ethemcan "at" kth.se. Arif Cem Gündoğan, PhD candidate in Earth System Science, Graduate School of Natural and Applied Sciences, Middle East Technical University, Ankara, Turkey. Acknowledgements: We are grateful to the guest editors of this Special Section, Connor Joseph Cavanagh and Tor A. Benjaminsen for bearing with us patiently. We also would like to thank three anonymous reviewers for their constructive comments, particularly to reviewer \#1 for her/his critical engagement. An earlier version of this article was published in Aksu, Erensü and Evren (2016) in Turkish. This is the fourth article in Connor Cavanagh and Tor Benjaminsen (eds.) 2017. "Political ecologies of the green economy", Special Section of the Journal of Political Ecology, 24: 200-341.
} 
développement de solutions de rechange à la post-politisation - sont les deux principaux défis auxquels est confronté le mouvement environnemental dans le pays.

Mots-clés: l'économie verte, la post-politisation, Turquie

\section{Resumen}

La economía verde a menudo se define como una configuración económica que resulta en mejoras en el bienestar humano y la equidad social, mientras que reduce (o por al menos disgrega) riesgos ambientales. Sin embargo, también es usada en cuando se requiere una lógica para mantener las bases estructurales de la economía política global. Como tal, los críticos de la economía verde aputan a menudo hacia su autocontradictoria naturaleza al tratar de legitimar y dar coherencia a diversas políticas públicas. La noción de economía verde es imprecisa y puede ser interpretada como una nueva forma para asegurar y mantener la acumulación del capital, de la mano con políticas de austeridad neoliberales. Este artículo hace una revisión crítica de la post-politización de la economía verde siguiendo su construcción social y creación de significado. Para lograrlo, se enfoca el debate de la economía verde en las post-politización de medio ambiente en Turquía, un país de rápido desarrollo con bastantes retos socio-ecológicos. Dicho análisis sugiere que la economía verde se volverá más importante cuando Turquía busque cumplir con los acuerdos ambientales internacionales. El artículo expone el reporte previo de Turquía para la Cumbre de Rio+20, titulado: "Reporte de Desarrollo Sustentable de Turquía: Asegurando el Futuro 2012”. Encontramos que la economía verde sirve como una útil herramienta discursiva para legitimar el asalto frontal a los ecosistemas turcos que se presentan principalmente en el sector energético y que son facilitados por el estado y regulados por el mercado. El argumento es que un evidente rechazo a dichos marcos y el desarrollo de alternativas a la post-politización, son los dos retos claves que enfrenta el movimiento ambiental en el país.

Palabras clave: economía verde, Turquía

\section{Introduction}

Whenever there is an issue about coal plants and nuclear plants some people stand up and do environmentalism. So why these things do not happen in the Western countries, why there are no such campaigns over there? The intentions of those who finance these campaigns are different. They are not after reaping the fruit and protecting the environment, they are after beating the farmer, they are after beating Turkey. (President Recep Tayyip Erdoğan, 7 November $2016^{2}$ )

In Oscar Wilde's four-act comedy Lady Windermere's fan (1892), Lord Darlington answers the question "What is a cynic?" with "A man who knows the price of everything and the value of nothing." We are living in an era in which the green economy is a cynical answer to the ecological crisis, with its climate, energy and food dimensions. The green economy and its various versions have become a new political mantra for the 21st century, particularly when urgent planetary challenges were not being met fairly or adequately, for example in the SDGs (Sustainable Development Goals) and the lead-up to the 2016 Paris Agreement. Analysing new proposals to maintain capital accumulation requires scrutiny, given neoliberal capitalism's cyclical social, ecological and economic crises. The main aim of this article is to dissect the post-politics of green economy discourse in Turkey, a country that increasingly knows the price of everything but the value of nothing.

In most general terms, a green economy is defined by the United Nations Environment Programme as an economy with "improved human well-being and social equity, while significantly reducing environmental risks and ecological scarcities" (UNEP 2011: 9). In elaborating this concept, some commentators indicate that the green economy can also be defined as an economy with abundance of green features, including interventions such as "improvement of the environment quality and protection

\footnotetext{
${ }^{2}$ Cumhurbaşkanı Erdoğan: "Greenpeace'ci bizim Karadeniz'e hep bela oldu" (Greenpeace guys always caused trouble for our Black Sea region), 7th November 2016. URL: http://www.birgun.net/haber-detay/cumhurbaskani-erdogangreenpeace-ci-bizim-karadeniz-e-hep-bela-oldu-134629.html
} 
of the eco-system from potential dangers through construction of solar panels, bio-fuel and hybrid vehicle production, organic agriculture, insulation, construction of huge wind turbines in low carbon and sustainable economies" (Özsoy 2011). Therefore, with all its ambiguity and fuzziness, it is possible to approach the concept of the green economy as a form of capital accumulation accompanying austerity policies, used to boost local economies in the face of the latest accumulation crisis of capitalism as it presses hard against planetary boundaries) through extractivism and appropriation of natural assets (Rockström et al. 2009.

In the next two sections we present an analysis of post-politics, its relationship with political ecology, and the green economy. Section 4 follows the development of green economy discourse in Turkey since 2009 and examines a key policy document prepared by the Turkish government in the runup to Rio+20 Summit, Turkey's sustainable development report: claiming the future 2012 (Ministry of Development 2012). In the fifth and the last section, we underline that global experience with the green economy and the moves initiated to support it in Turkey are actually greenwashing - of familiar attempts to deregulate the economy to boost industrial competitiveness, venture new accumulation methods for the private sector, and dissociate the environment from the political.

\section{The post-politics of political ecology}

While making these investments we are also taking the natural life into consideration. We know that most of the [environmentalist] criticisms in the media in this regard are ideological. On the other hand, we are already taking reasonable and sincere criticisms into account and we are examining them. Just like in the case where we consider the balance between democracy and security, we are continuing our balanced approach between development and environment. No one shall have any doubts on this. But we should not forget; while preaching environment, we should not forget to say that human comes first. Because humans come before anything else. The living conditions of our people are very crucial for us.

President (then-Prime Minister) Erdoğan talking during the opening ceremony of the Seyrantepe Hydroelectricity Plant, Peri Suyu (Milliyet, 18 May 2008)

It will not be an understatement to say that Gezi Park protests of 2013 were the culmination of a politicization of environmental debate in Turkey (Akbulut 2014; Kuymulu 2013; Özkaynak et al. 2015). This had been in the making for the previous two decades (Adaman and Arsel 2005; Adaman et al., forthcoming). ${ }^{3}$ Ecologists (or 'environmentalists' as frequently referred to in the media ${ }^{4}$ ) found an opportunity to position themselves against state-driven (or facilitated) neoliberal developmentalism. This has provided a valuable opportunity for the re-construction of the commons from the bottom up, overcoming the rural-urban dichotomy, and launching counter-attacks against mainstream environmental politics. From this vantage point the Gezi protests can be read as an oppositional positioning against Turkey's rapid economic growth (and its peculiar political, economic, cultural zeitgeist), and now its downward economic spiral (Onaran and Oyvat 2016). Hot money ${ }^{5}$ driven by foreign direct investment is linked to an expanding social metabolism (Muradian et al. 2012) and continuation of capital accumulation through relentless commodification of the commons. The Gezi protests paved the way for overcoming not only nationalist-conservative social congestion and neo-Islamist authoritarian rule, but also surpassing

\footnotetext{
${ }^{3}$ Public protests began in Istanbul in Taksim Gezi Park, over government plans to redevelop it, and then violent actions to clear a sit-in. Protests and strikes spread across Turkey, protesting lack of press freedom, attacks on secularism, and other issues. The protests were forcefully suppressed.

${ }^{4}$ Dobson's Green political thought makes a distinction between environmentalists and ecologists: "Environmentalism argues for a managerial approach to environmental problems, secure in the belief that they can be solved without fundamental changes in present values or patterns of production and consumption, and, ecologist thinking holds that a sustainable and fulfilling existence presupposes radical changes in our relationship with the non-human natural world, and in our mode of social and political life" (Dobson 2007: 2-3).

${ }^{5}$ Flow of capital between countries to earn short-term profit on exchange rate or interest rate differentials.
} 
existing technocratic environmental management. This also involved leapfrogging ecological social movements that limited themselves to narrow NIMBY (not in my back yard) approaches, to contributing to NIABY (not in anybody's back yard) or in its most extreme, BANANA (build-absolutely-nothinganywhere-near-anything) perspectives (Uncu 2016; see also Schively 2007 for a detailed discussion of these concepts). In this regard, the Gezi protests brought ecological conflicts to the forefront of highly polarized Turkish politics while making a counter-statement against the de-politicization of environment by the state, the private sector, and some sectors of civil society. ${ }^{6}$ Arguably,these protests also gave rise to what Mert (2016: 5) calls as "semantic constellations of ecological conservation, cultural pluralism, and democratisation merged in opposition to the hegemonic hyper-developmentalist discourse." In this article, we focus in particular on the post-politicization of environmental politics within this context.

In the introduction of her book On the political, where she begins by indicating that she will interrogate the post-political zeitgeist, Chantal Mouffe asks this legitimate and thought-provoking question:

There is much talk today of 'dialogue' and 'deliberation' but what is the meaning of such words in the political field, if no real choice is at hand and if the participants in the discussion are not able to decide between clearly differentiated alternatives? (Mouffe 2005)

The issue Mouffe touches on here indicates the depletion of the political field in a dominant language of morality in politics. This post-political field concretizes by refusing (or ignoring) political categories such as right and left, preferring the ethical dichotomies labelled as right and wrong for every decision (Mouffe 2005). In this way, the post-political vision proposes wholesale removal of ideological confrontations. In line with the attitude of neoliberal doxa sophists (public opinion engineers/technicians) ${ }^{7}$, such preferences open a way for a vision of the politics "beyond the right and left."

Mouffe (2005) asserts that the individualism that is framing liberal thought does not provide opportunities for making sense of collective identities. According to her, the moments of dichotomy (antagonism) resulting from contentious subjects "disclose the limits of each rational consensus through revealing the inevitable moments of decision" (Ibid). In this sense, she suggests that the individualization process that is entailed by liberal modernity annihilates collective modes of living, paving the way for collective consciousness and the political imagination emanating from that consciousness. Hence; a postpolitical vision of our era positions its opponents on ethical rather than political grounds, encoding them as the "enemies" that should be removed, rather than as different 'antagonists' that should confront each other politically (Ibid: 89). In the absence of a perspective that opens up the political, this situation results in stigmatization of all opposition against neoliberalism as 'traditionalist' or 'fundamentalist.' Post-political vision, in this regard, will either integrate the opposition into the system by means of a deliberative approach, or it will exclude it. More often than not, a permanent condition of the 'state of exception' ${ }^{8}$ comes into existence for those who are radically excluded from the system.

According to Wilson and Swyngedouw (2014), post-politicization is a process where decisionmaking processes are locked into buzzwords such as "participation of stakeholders" and "good governance" by means of the exclusion of alternative ideas and imagination. In this way, decision-making processes that do not constitute any threat to neoliberal consensus are created by trimming their extreme edges. A post-political status can be defined as "the situation in which the politicization of individuals is prevented through the closure of the political" (Swyngedouw 2010). Swyngedouw argues the problems

\footnotetext{
${ }^{6}$ See also Turkey's map of ecological conflicts: www.direncevre.org .

${ }^{7}$ Doxa refers to "the universe of opinions that the complementary class if defined, the class of that which is taken for granted" according to Bourdieu (1977: 168). Doxa sophists, in this formulation borrowed from Emrah Göker and H. Bahadır Türk, indicates 'public opinion engineers/technicians.' For a detailed discussion on doxa sophists during the AKP government, see Göker (2009) and Türk (2012).

${ }^{8}$ Police blockages and media blackouts during the Gezi protests can be seen in this context. From the $7^{\text {th }}$ June 2015 election, the country plunged into a significant downward spiral of violence. A key strategy of Erdoğan's strategy to quell social unrest was media censorship and throttling social media.
} 
begin by basing green politics on the existence of only one nature, and the 'environment' is seen as subservient to the functioning of the economy. He suggests, in contrast, that human constitute part of nature, permanently transforming it at different spatial and temporal scales in the Anthropocene (and across biological, chemical, and geological processes) (Swyngedouw 2014). For this reason, rejecting nature as a political actor ${ }^{9}$, renders it politically mute (Swyngedouw 2010).

The post-political vision conforms to the neoliberal consensus, and sees environmental, social, economic and other domains as technical issues managed through consensus, discretion and deliberative policy formation. Žižek (2002) asserts that the hallmark of such kind of post-politics is the rise of technocratic administrative approaches. The state administration (and concomitantly socio-ecological structures it depends on) becomes less political, deploying governance ${ }^{10}$ through competent experts and technical knowledge. Controversies are not permitted, apart from disagreements between elites and technical experts over choice of technologies, the details of administrative arrangements, and timescales for implementation; different socio-political narratives are excluded, and there is less concern for the future (Swyngedouw 2010). Therefore, post-politicization of environmental politics rejects the political aspect of public issues, like opposition to Gezi Square redevelopment, favoring technocratic mechanisms. Essentially, a post political organization will support neoliberal capitalism, a representative parliamentary system, and charity (Swyngedouw 2011). Just as Rancière (1991) describes post-democracy as "a democracy after the demos, a democracy that has eliminated the appearance, miscount and dispute of the people and is thereby reducible to the sole interplay of state mechanisms and combinations of social energies and interests", the green economy can be described as a post-political approach, a green breed of capitalist accumulation whose basis is embodied by the market mechanisms initiated, facilitated and supported by the state through expropriation and dispossession.

\section{Green economy: green-washing wholesale commodification}

Erdoğan commenting on the environment organization, Greenpeace, said: "They are attacking here and there, they said that you could not construct dams, you would damage the nature. Diseases and dirtiness exist in places without water storage, where the water is absent. They are saying no again because their approach is ideological."

President Recep Tayyip Erdoğan giving a statement during the National Forestation Mobilization and Opening Ceremony of the first phase of the Melen Intrabasin Water Transfer Project. (Hürriyet, 3 December 2007)

Sustainable development entered the international political scene for the first time through the report titled Our common future (1987), prepared by a United Nations (UN) commission chaired by the former prime minister of Norway, Gro Harlem Brundtland. It was also a response to the earlier The limits to growth (1972) report published by the Club of Rome during a period of oil crises and debate over rising global population. A year after the collapse of the Berlin Wall, there were a series of UN meetings in Thailand (education) and New York (children), and then Rio (environment), Vienna (human rights), Cairo (population), Copenhagen (social development), Beijing (gender), Rome (food security) and Istanbul (human habitat) (Vandemoortele 2013). These global summits were typically based on the principles of ecological modernization - sustainable development without unduly challenging economic growth and private companies. The most distinctive among this series of conferences was the UN Conference on Environment and Development (UNCED) of 1992 in Rio de Janerio, where sustainable

\footnotetext{
${ }^{9}$ Despite the serious shortcomings in implementation (Andreucci and Radhuber, in press), 'Rights of Mother Earth' articles in the Bolivian and Ecuadorian constitutions show how nature can be constructed as as a legal and political subject (Özlüer et al. 2012).

10 The ifference between government and governance is not only that the second is a reciprocal verb. It also neutralizes the possible opponents of government through integrating them into itself.
} 
development was taken to the world stage and three major international environmental regimes were launched. ${ }^{11}$

The idea of the green economy, the subject of this Special Section, came to the attention of the global policy circles during the Rio+20 conference that was organized in 2012. Although the first usage of the concept could be traced back to Pearce, Markandya and Barbier's (1989) report titled Blueprint for a green economy, the launch of Green Economy Report prepared by UNEP during the Rio+20 preparatory process is significant (UNEP 2011). In UNEP's account, green economy denotes a development scenario proceed through "investing in systems decreasing carbon emissions and pollution, enhancing energy and resource efficiency and preventing loss of bio-diversity while increasing revenues and employment" (UNEP 2011). Therefore, the green economy is "an economy that enhances the human welfare and social equality while depreciating environmental risks and ecological scarcities" and "[...] in its simplest form, the green economy can be defined as low-carbon, resource efficient and socially inclusive" (ibid.). The report argues a green economy can be constructed by removing or decreasing economic support mechanisms that are harmful for the environment, using regulatory institutions and policies to curb externalities or asymmetric information affecting markets, and by embedding "green procurement" in the public sector to encourage private sector investments in green services and/or products (Cavanagh and Benjaminsen 2017).

Wanner (2015), in his detailed critique of this report, dispels the myth that green economy can decouple environmental degradation and pollution. He suggests that green economy discourse "depoliticises other dimensions of sustainability (social, cultural and political dimensions) which further undermines the possibility for social and environmental justice and sustainability" (ibid. p.36). In a similar fashion, Brockington (2012) suggests that "the main contribution of this report is to force opponents to explain precisely what is not to be followed." Fierce critics like Ulrich Brand (2012) perceive the green economy as a strategy combining diverse and partially conflicting opinions and interests, and stresses that the term is an oxymoron. Capitalist accumulation's inevitable pressure upon the (increasingly visible) ecological limits of the planet ${ }^{12}$ (the most distinctive aspects being ecological destruction from energy production to waste disposal) paved the way for the urge to paint 'development' green. Brand draws attention to the fact that green economy is a proposal aiming at ecological improvement through accumulation. It is not a system that prioritizes humans and the environment, but perceives them to be cheap and accessible (as natural and social capital). An approach that can reverse this is only possible through abandoning efforts to reform capitalism once and for all.

The green economy is aligned with strategic economic interests of the global North and characterized by intermeshing of ecosystems, global capital and technocracy, based on old fossil economies and technical fixes (Brown et al. 2014). The concept, which became globally popular through the Rio+20 Summit, progresses along two main axes. The first of these is conceptualization of 'natural/environmental capital' and the second is mainstreaming 'payment for ecosystem services.' Natural capital indicates transformation of nature into capital/raw material, transforming it as an input for economic processes; protection of this capital is required for the payment of ecosystem service costs. Proponents anticipate that ecologically harmful activities will lose their economic attraction through pricing the ecological costs of environmental services. Costs of ecosystem services protecting natural assets should be identified and maximized (delivery services such as clean water, fuel, food; regulatory services like local meteorological cycles and mitigation of disaster impacts; supportive services as biomass and oxygen production; and socio-cultural services provided by habitats). In summary, a price should be found for oxygen-producing forests and river basins, and to integrate them into the market. Hence it is not surprising that the TEEB ${ }^{13}$ project that ran between 2007 and 2011 was called Terrible

\footnotetext{
${ }^{11}$ UNFCCC (United Nations Framework Convention on Climate Change), UNCBD (United Nations Convention on Biological Diversity), UNCCD (United Nations Convention to Combat Desertification).

${ }^{12}$ EROI (Energy Return on Investment) refers to energy return from one unit of investment. As observed by Scheidel and Sorman (2012), decreasing fossil fuel stocks and EROI values can lead to uptake of alternative energy resources that have less energy intensity like bio-fuels and hydroelectric power plants (ie. watergrabs, see also Islar 2012 and Erensü 2015). Under the assumption that the demand for energy will continue to increase at the same rate, very large land areas will be needed for biofuels.

${ }^{13}$ The economics of ecosystems and biodiversity http://www.teebweb.org.
} 
economics, ecosystems and banking by Clive Spash (2011). The final document of the Rio+20 Summit titled The future we want, is no exception. It provided a rationale for expansion of the green economy concept.

Coinciding with the Rio+20 meeting, members of the Indigenous Environmental Network (IEN) gathered in Kari-Oca, which is located near to Rio de Janerio to accuse the green economy advocates of diminishing the food sovereignty of indigenous people through carbon markets and land grabbing. They saw the green economy as incapable of addressing the existing crisis. Unlike the rather vague concluding declaration of the Rio+20 Summit, the final declaration of this meeting was lucid and uncompromising:

We see the goals of UNCSD Rio+20, the "Green Economy" and its premise that the world can only "save" nature by commodifying its life giving and life sustaining capacities as a continuation of the colonialism that Indigenous Peoples and our Mother Earth have faced and resisted for 520 years. The "Green Economy" promises to eradicate poverty but in fact will only favour and respond to multinational enterprises and capitalism. It is a continuation of a global economy based upon fossil fuels, the destruction of the environment by exploiting nature through extractive industries such as mining, oil exploration and production, intensive monoculture agriculture, and other capitalist investments. All of these efforts are directed toward profit and the accumulation of capital by the few. [...] The Green Economy is nothing more than capitalism of nature; a perverse attempt by corporations, extractive industries and governments to cash in on Creation by privatizing, commodifying, and selling off the Sacred and all forms of life and the sky, including the air we breathe, the water we drink and all the genes, plants, traditional seeds, trees, animals, fish, biological and cultural diversity, ecosystems and traditional knowledge that make life on Earth possible and enjoyable. [...] We will walk in the footsteps of our ancestors. (IEN 2012)

Decreasing the amount of carbon intensity per unit of production, and decoupling of economic growth from fossil fuel consumption is a central claim of green economy advocates. With the increase of efficiency in industrial processes in recent decades, the world witnessed a reduction global carbon emissions per unit of economic activity from 1kg/US\$ to 770gr/US\$ (Hoffman 2011). Assuming the world population reaches 9 billion by 2050 and 2\% annual economic growth is sustained, it is necessary to decrease the carbon intensity to $6 \mathrm{gr} / \mathrm{US} \$$ in order to limit climate change at well below $2{ }^{\circ} \mathrm{C}$ (Hoffman 2011). As Hoffman says, the Paris Agreement ratifies a target that is 130 times lower than present carbon intensity. The view that economic growth can be decoupled from material and energy consumption, without acknowledging asymmetrical market structures; uneven subsidies, and global supply chains of goods and services is misleading. In the absence of a thorough reconfiguration of the economy, a fair redistribution of wealth and abolition of the global consumer culture; any intervention will only provide another confirmation of what Nicholas Georgescu-Roegen, one of the founding fathers of ecological economics who blended the physical limits of our planet with the rules of thermodynamics, indicated in 1970s: "Bigger and better washing machines, automobiles and super jets must lead to 'bigger and better' pollution"' (Georgescu-Roegen 1970: 19). This "bigger and better pollution", we argue, also constitutes the intellectual background of the Claiming the future report of the Turkish government, which we analyse in the following section.

\section{The green economy that (re)claims the future? Turkey's Sustainable Development Report 2012}

Even today, a mentality which still perceive itself as the only environmentalist, which perceives itself or any decision regarding to environment as its own right, which announces others apart from itself as enemies of the environment still exists. To put it plainly, this mentality, which nestles environmental sensitivities and ideological views, does not serve for protection of the environment, on the contrary; it has been the reason or responsible 
body of several environmental disasters due to its ideological attitude. Moreover, this mentality even positioned itself against any kind of transformation, progress, improvement and development hiding behind the image of environmentalism. They oppose nuclear energy on the grounds of environment, they oppose electricity production through dams in the name of environment.

President Recep Tayyip Erdoğan speaking to public at the delivery ceremony of 103 solid waste collection vehicles funded by the Ministry of Forestry and Water Affairs (Ministry of Forest and Water Affairs, 30 March 2011)

Nur Betül Çelik (2010: 160) explains the departure point of a post-political vision as "the desire to construct a world beyond the right and left, hegemony, sovereignty, antagonism." The post-political green economy appears in this way. Its win-win perspective and lack of ideological leanings is visible in the major international reports described above. One the most important political documents prepared for the Rio+20 process was Sustainable development in Turkey: claiming the future 2012 (Ministry of Development 2012 (hereafter CTF). It was prepared in September 2011 by the Ministry of Development with the participation of numerous stakeholders including private sector and civil society organizations. Its significance is that it lays out sustainable development and green development goals for Turkey. Critical analysis of this report helps us to better understand the post-political official ideology behind the last five years of state policmaking.

Discourse and content analysis, in its simplest definition, is a method disclosing the underlying worldview and vision of a text by focusing on the keywords and opinions used, the framework within which a topic is discussed, and the use of wording, definitions, problems and solution statements. We identify presences and absences in the document by focusing on the meaning making by the report. It is useful to start by looking at the green economy definition adopted by the state:

[...] Green development" or "green economy" concept is defined as an approach prioritizing investment and consumption of goods and services contributing to environmental improvements. [...] However, what is covered by the concept of green economy in general is not clearly identified, and a widely accepted definition of it does not exist. For this reason, countries are putting their specific definitions in accordance to their unique conditions. (Ministry of Development 2012)

The report represents the lowest common denominator of the stakeholders in the environmentdevelopment nexus in Turkey. Radically different opinions were trimmed in the process of consensusbuilding, and integration of these into the report with much softer edges. In order to reveal the spectrum of this approach, we will firstly focus on the introduction section, followed by the three parts of the report (Turkey's green development approach for sustainable development; economic, social and environmental developments; the green development roadmap of Turkey for its sustainable development).

\section{CTF: introduction and conceptual framework}

In the introduction part of CTF report, much of the attention is drawn to the progress of Turkey in positioning itself as a key "actor" over the previous decade, determined to contribute more to combat global problems. Departing from this, the report repeatedly mentions that transparency and participatory approaches were central in preparatory research, and the efficacy of dialogue between the stakeholders was crucial. ${ }^{14}$ Quantitative indicators are used, discussing Turkey's progress towards sustainable development, and the reforms already undertaken. After this introductory section, the aims are given:

\footnotetext{
${ }^{14}$ Turkey's sustainable development report: claiming the future 2012 was prepared under the coordination of the Ministry of Development in the framework of Rio+20 Summit preparations, with participation by 1,300 people from 55 institutions. There were two briefing meetings, three workshops with broad participation, four regional workshops, NGO and private sector dialogue meetings and four round table meetings. On this basis, the report claims to be an outcome of participatory analysis.
} 
The aim of this report is evaluating the works undertaken on Turkey's sustainable development process, expression of policies that will be undertaken in the future and identification of the national vision, and assessment of the contributions which can be provided by our country for the solution of global problems. (p. 2)

At the same time, green development is given as a goal, but without a definition. Throughout, green development is said to contribute to comprehensive economic, social and environmental policies.

According to the report, Turkey will enhance green development in accordance with its "relative capabilities" (p. 2), and will evaluate the opportunities and the risks (of a green economy), will establish a (business) environment in which it can manage these, will develop the tools appropriate to national conditions, and will try to maximize incomes at the local level. This section repeatedly indicates that Turkey, as a "developing country" will continue to develop economically; while doing this, the social benefits (i.e. a trickle down of wealth) will be increased with economic and social policies in harmony with the natural environment. The report does not question prioritizing economic development, and the continuous need for it, except in relation to the nation's status. In the case that environmental destruction is inevitable, it should be minimized (stating inevitability prevents a substantial debate on 'how' and 'why' of development, see also Arsel 2012). On the other hand, the main motivation is clearly indicated as enhancement of the 'competitive capacity' and 'efficiency' of the sectors. These two concepts, by being repeated as leitmotiv in the report, constitute the framework of the green economy perspective. The role of the private sector is defined as "the most important player" in the development of new financial tools in this process. At the end of the introductory section, sharing Turkish "experience and lessons learnt" with other countries is underlined as a mission. ${ }^{15}$ The desire for popularization of these development experiences, that is to say, replicating the local development mantra as a "white man's burden", is mentioned several times in relation to the global objectives of the Turkish government.

To briefly summarize, we claim that the sustainable development vision of CTF report is one based on the Brundtland Report, in which development is perceived through the lens of economic development, and the main driver of change is inter-sectoral competition and enhancement of efficiency. International environmental regimes assist in attaining this vision in a utilitarian manner, and Turkey declares itself to be a 'development role model' for neighbouring countries.

\section{CTF: Turkey's green growth for sustainable development approach}

The next section in CTF report is titled Turkey's green growth for sustainable development approach. It again fails to specify what is meant by 'green development'. In the first part, which outlines the need for a green economy, Turkey is said to adapt a human-centred development vision through the strength taken from its history and cultural heritage, with strong historical references to a mighty Ottoman past. Turkey reclaims its future from today. Any benefits from development should be distributed fairly. This section also goes on to say that the most vulnerable social groups (definitions are unclear) will be empowered through equal opportunities to use natural and social resources. In discussing the global green economy discourse, the report mentions the increasing skills of the national labor force, effective management of environmental risks, intergenerational justice, minimization of resource scarcity, effective use of technology and a future vision prioritizing resource efficiency in both production and consumption. It is not surprising to see that generic green economy propositions get repeated in reference to Turkey's own approach. Commentators suggest an ecologically destructive development route will result, by becoming an 'energy hub' for the region (Dombey 2014).

The report asserts that political and economic stability in Turkey is the sine qua non for sustainable development. Considering the absolute control of the Turkish government over development processes and its reluctance to delegate administrative power to decentralized bodies, it is not surprising

\footnotetext{
15 The role played by Turkish International Cooperation and Development Agency (TIKA) in exporting Turkey's development experience to other developing countries is not mentioned. On this point, see Kulaklıkaya and Nurdun (2010).
} 
that this macroeconomic structure is proposed as the "guarantee" of social and environmental improvements. On top of this, the absence of a comprehensive approach to environment-development relationships should be underlined. According to the report, protection of the environment is considered important insofar as it enhances economic competitiveness, alongside legislative and institutional governance mechanisms to make space for development. It also highlights existing problems of implementation (inadequacy of control mechanisms, lack of awareness, absence of coordination between different institutional bodies etc.). Interestingly, there is emphasis on the necessity of improvement in private sector opportunities, skills and competencies, while the existing structure of the public sector is perceived to be sufficient. All of this is a dose of post-politicization, deflecting attention from the state.

Green economic development, according to the report, will be supported through prioritization of energy efficiency and renewables, in order to decrease dependency on imported energy. In fact, the green economy turn is useful for the Turkish government, which is striving to quench its thirst for energy with multiple nuclear and domestic coal investments. Several activities will support sustainable development targets, according to CTF. These include the steps being taken for food and water security, decreasing the ecological impacts of road transportation, taking advantage of ecosystem services provided by the forestry sector, urban transformation, construction of new settlements, studies to combat climate change (sic), decreasing the greenhouse gas emission intensity in productive sectors, and an increase in material use efficiency. The green economy is said to provide additional employment opportunities. Where resistance to hydropower development has occurred, the report proposes there will be long-term secure intergenerational employment. In reality, hydropower investments provide temporary and unqualified employment with low salaries ${ }^{16}$, mostly through insecure contracts and generally to low-skilled young men (Ulaş 2010).

\section{CTF: economic, social and environmental developments}

There are four sub-sections. The first summarizes economic development and the benefits of reform, including the public administration. The main issues are: positive developments in economic indicators such as gross domestic product (GDP), per capita national income, lending requirements, inflation, the balance of payments and employment. The economic growth rates of Turkey are underlined, but also its high public deficits, high inflation and debt-interest trap. A Transition to powerful economy program is proposed. ${ }^{17}$ While noting Turkey's rapid economic growth rates between 2001 and 2011, key successes were also growth in per capita income, government savings, public interest payments and direct investments, and a decrease in public deficits with navigation of single-digit inflation.

More recent analysis suggest this period of growth is over (Acemoğlu and Uçer 2015). The sectors with highest growth from 2001-2011 were industry (4.6\%) and services (5\%). In 2011, the service sector makes up $68.2 \%$ of the economy, against industry (22.6\%) and agriculture (9.2\%). The CTF report claims that tourism is growing as part of services. But other studies show growing urbanization along the attractive coastlines, as well as mass tourism with heightened $\mathrm{CO}_{2}$ emissions (Burak et al. 2004).

Turkey imports primary energy to meet its needs. The report does not question the sizeable need for energy, only its importation. Erdoğan's statement on the budget deficit in 2014 was:

We have been closing our budget deficit with hydroelectricity, coal-fired thermal power plants and renewable energy investments. In a period of 3-5 years, budget deficit will totally be a thing of the past for Turkey. ${ }^{18}$

\footnotetext{
${ }^{16}$ The other side of the "green economy" is the Chinese workers employed as the cheapest of the cheap labour force in "dirty energy" thermal plants in Zonguldak (see Atlı 2010). Turkey has the worst ranking among OECD members in terms of fatal industrial accidents and is the $2^{\text {nd }}$ worst behind China (Müller 2014). Low labor costs are what the capital investors look for, whether in a green or grey economy.

17 Officially launched by the ousted Prime Minister Davutoğlu on 06/11/2014, this programme gives particular financial incentives to coal-power development.

${ }^{18}$ Türkiye daily newspaper, 8 January 2014.
} 
Reading between the lines, it is not difficult to see that energy investments are distancing from a holistic, socially relevant approach based on needs and capabilities. Instead, fixing the budget deficit and other economic ills involves head-on energy production and extractivism in ecologically vulnerable areas. A recent example was in Yirca village, in western Turkey where 6,000 olive groves were cut overnight to build a coal-fired thermal power plant (Turhan 2014). ${ }^{19}$ When asked about this during his weekly press briefing, former deputy Prime Minister Bülent Arınç commented:

There are olive groves all over the country thanks to the incentives our government has provided. Even mountains and high plains are full of olive trees. Those trees have created a lucrative industry, but Turkey needs energy too. (Hürriyet Daily News 11 November 2014)

New investments have been attracted by a privatization of public assets, increasingly precarious labour conditions maintained partly due to an influx of Syrian migrants, and Turkey's place in global geopolitics. Nonetheless, the productive economy is shrinking, and the currency exchange rate is poor. The state is trying to improve macroeconomic indicators but is not following an inclusive and holistic development pathway. The CTF report is revealing: it does not say dependency on fossil fuels is a big problem, only dependence on energy imports. ${ }^{20}$ Cabinet members actually equated an increase in energy consumption with 'development', and even branded opposition resistance to energy investments as "resistance against development" (Sabah 27 December 2013).

The second sub-section presents developments and reforms undertaken from the 2000s: equal opportunities, fairer redistribution of wealth, the fight against poverty, and increases in social services. A social dimension is important for economic improvement, and vice-versa. Figures on population and demographic structure place some emphasis on the environment. The report notes that Turkey's population rose from 57 million in 1992 to 74.4 million in 2011. This, according to the report, constitutes a "serious pressure." The only factor negatively affecting sustainability is population increase (almost in a Malthusian way); making questioning issues such as consumption trends and the neoliberal economy difficult. Population is proposed as an economic force (with development and economic growth identified through macroeconomic indicators) but also becomes the basis of problems.

When we look at the third section in which environmental progress is explained, the Brundtland definition is repeatedly revisited and it is argued that success is achieved through: control of greenhouse gases, use of renewable energy, enhancement of energy efficiency, improvement in waste management, expansion of sanitation and sewage services, enlargement of forests and protected areas, and conservation of biological diversity. We will focus on particular points and insights. Using the per capita energy consumption as an indicator of development is problematic since it does not denote who uses energy and to what end. Similarly if we argued that income inequality has a positive impact and military expenditures have no significant effect on Turkey's economic growth, this does not mean that we should promote either - leading to income inequality or war (Töngür and Elveren 2016). This section of CTF report also includes statements through which attitudes towards renewable energy can be traced. Turkey's high potential for energy production is again mentioned, including 2007 incentive mechanisms. They include exemption from license/permit fees and various customs taxes, providing assistance in land allocation, a discount on fees for utilities connections, and electricity supply guarantees and feed-in-tariffs for renewables. ${ }^{21}$ The approach is technocratic - a private-sector-led energy transition without considering its socio-economic dimensions or any role in ecological destruction. Alternative perspectives on 'development', like insuring social justice, are hidden.

\footnotetext{
19 The Cerattepe gold mine (northeastern Turkey) is another recent example of a full frontal extractivist push rationalized by public budget concerns.

${ }^{20}$ Erdoğan's government also legitimizes its recent 'coal rush' with a need to reduce energy imports, in part due to the lingering geopolitical tension with Russia. Despite clear disagreements on the Syrian crisis, Turkey opted to reconcile with Russia due to its very high level of hydrocarbon dependency.

${ }^{21}$ Feed-in tariffs are financial incentive systems often used to support renewable energy technologies (i.e. photovoltaic energy). A feed-in tariff model includes i) access to the electricity grid, ii) long-term and guaranteed purchase contracts and iii) pricing that covers installation and running costs.
} 
The CTF report devotes some space to the rise of hydro-energy production since 1990s. While the number of purchase-guaranteed, build-operate-transfer model hydropower plants has increased, inflation in consumer prices and purchase guarantees have strained the public budget (Başkan 2011). Profits have bee promised by the voluntary carbon markets, which commodify the atmospheric commons. Yet even market actors confirm these voluntary markets are the "wild west of the carbon trade", lacking transparency and accountability and with dubious greenhouse gas emission reductions (Hamilton et al. 2008). ${ }^{22}$ More realistically, they offer "accumulation by decarbonisation" (Bumpus and Liverman 2008).

In the CTF, arguing that climate change is the result of rising energy consumption and economic activities since the early Industrial Revolution helps absolve Turkey of historical responsibility (with $0.4 \%$ of cumulative global greenhouse gas emissions, and its late industrialization). An interesting point is that Turkey's rising greenhouse gas emissions are now strongly connected with economic growth and energy consumption, rather than rather population growth. Yet, the framing of CTF doesn't acknowledge this. It emphasizes that Turkey's climate change battle is undertaken "with its own resources" and that it decreased its emissions by 20\% compared to the 'business-as-usual' scenario between 1990 and 2007 (p. 24). The coincidence of a $171 \%$ increase in GDP over the period with a decrease in emissions intensity for each GDP dollar (decreasing to $0.36 \mathrm{~kg} \mathrm{CO}_{2}$ ) is given as a supporting argument for Turkey's on-going transition to a green economy. ${ }^{23}$

The final sub-section is focused on Turkey's international role and its presence in several environmental agreements and conventions ${ }^{24}$, arguing that efforts to join the EU have positively contributed to the harmonization of national legislation with the institutional and technical structure that EU membership requires. The sustainable development concept now appears in basic political and legal documents. But to reiterate, the main rationale for Turkey's environmental commitments, according to $\mathrm{CTF}$, is the "protection of international competition capacity of the private sector." In doing so, the report reiterates Turkey's willingness to enter into financial partnerships with the World Bank and other agencies, even though the development vision and the environmental record of the former is not overwhelmingly positive (Goldman 2006). This includes receiving international loans for several hydropower and coal-fired thermal power stations. The sub-section also refers to permanent and temporary environmental commissions now in place under the Parliament, and the National Sustainable Development Commission (NSDC) established by the Ministry of Development in 2004. This should be the responsible body for political ownership of environmental investments. These should involve "decreasing [material] input costs" and "increasing efficiency" (p. 36). Again, the environment is just an input to the economy ("knowing the price of everything but the value of nothing").

\section{CTF: Turkey's green roadmap for sustainable development}

The final part of the report presents the "green economy road map for Turkey." It argues for holistic assessment of socio-economic structures and the environment, to ensure current and future generations will benefit equally from the opportunities brought by development. In this sense, the green economy in Turkey is perceived as "a tool for economic development and growth that is marked with efficient use of natural resources, prevention of environmental depreciation, decreasing poverty while increasing wealth and employment, supporting innovative, efficient and clean technologies" (p. 39). Future success in sustainable development is linked to policy and legislation, although deficiencies in implementation and lack of compliance control are recognized. Among the opportunities for green

\footnotetext{
${ }^{22}$ A latecomer to climate policy, Turkey is still in the process of setting up its carbon market which it wants eventually to integrate with global carbon markets (see Turhan et al. 2016). As of today, only voluntary carbon transactions are possible in Turkey.

${ }^{23}$ Absolute decoupling assumes that increasing economic outputs without any increase in environmental damage is possible. It is a cornerstone of the green economy. According to Jackson's take on decoupling, "the choice in order to see the light at the end of the tunnel we need is: we should increase resource efficiency (at least) as the rate of the increase in economic outputs [...] Unfortunately it is difficult to present a good example/proof showing that we did/can manage this." (2009)

${ }^{24}$ It should be underlined that Turkey systematically refuses to be a party to the Aarhus Convention on Access to information, public participation in decision-making and access to justice in environmental matters, which was opened for ratification in 1998, and came into force in 2001. Its title reflects its aim.
} 
growth, the report mentions prioritization of sectors that have heavy environment impact, those with high resource use, good competitiveness export potential and job creation, and those most affected by harmonization with EU legislation. These sectors are predominantly in the field of energy, transportation, industry, agriculture and services.

Some of the concrete targets relate to local and renewable energy sources, energy production and consumption, and better use of R\&D potential. They are:

- A 30\% rise in the share of renewable energy in electricity production by 2023. In 2012 the share of hydro-power alone was 22.8\% (Elektrik Üreticileri Derneği 2013)

- Decreasing energy intensity ${ }^{25}$ by at least 20\% in 2023 from 2011 levels, ensuring 20\% energy savings in public buildings and facilities by 2023

- Implementing energy saving measures in buildings, in industry, and providing recycling for low efficiency electronic tools (the issue of waste is not discussed)

- Modernization of coal and thermal plants

- Smart meter and network development and enhancement of R\&D support.

While these are thoughtful targets on their own, the ecological costs of the energy and industrial sectors are not integrated. Enhancement of the competitiveness of the Turkish economy is again the vision.

The report repeats established economic arguments. It promotes market-led 'consumer pays' and 'polluter pays' principles for natural resource use and pollution control, respectively. These are market mechanisms of neoliberal environmental governance, that assume environmental damage can be compensated solely by payment of reparations (Pearce et al. 1989). Democracy, the rule of law, and human rights emerge in the conclusion, if not in the main sections, as if to leave us with positive imporessions. Finally Turkey's expectations from the Rio+20 process are listed as follows: a just consideration of using its "right to development"; identification of global environmental targets; construction of an international regime in which all countries take part; re-characterization of the role of the private sector in attaining sustainable development; consideration of cumulative impacts in partitioning responsibilities; and - importantly - ensuring that green growth does not pose any obstacles for national competitiveness.

\section{Discussion}

You have to admit: this whole "catastrophe," which they so noisily inform us about, it doesn't really touch us. At least not until we are hit by one of its foreseeable consequences... It may concern us, but it doesn't touch us. And that is the real catastrophe. There is no "environmental catastrophe." The catastrophe is the environment itself. The environment is what is left to man after he has lost everything. Those who live in a neighbourhood, a street, a valley, a war zone, a workshop - they don't have an "environment", they move through a world peopled by presences, dangers, friends, enemies, moments of life and death, all kinds of beings. Such a world has its own consistency, which varies according to the intensity and quality of the ties attaching us to all of these beings, to all of these places. It's only us, the children of the final dispossession, exiles of the final hour - the ones who come into the world in concrete cubes, pick our fruits at the supermarket, and watch for an echo of the world on television - only we get to have an environment. And there's no one but us to witness our own annihilation, as if it were just a simple change of scenery, to get indignant about the latest progress of the disaster, to patiently compile its encyclopaedia. The Coming Insurrection (The Invisible Committee 2012: 49-50)

\footnotetext{
${ }^{25}$ Energy intensity here refers to unit of energy consumed per unit of GDP.
} 
There are environmentalists in the world. Actually, this expression is very good as a title. Yet, this civil society movement will be commendable if it is cleared from ideologies. On this condition, we will take side with such a movement without reservations. President Recep Tayyip Erdoğan, Opening speech of International River Basin Management Congress (Radikal 23 March 2007)

Departing with an ambition to 'reclaim the future', the CTF report depoliticizes the green economy mantra through integrating it in such a way that it obscures any alternative imaginaries to Turkey's current authoritarian, neoliberal, developmentalist politics. As Adaman et al. (forthcoming) also say, modernization and economic development in Turkey are collective aims, designed so by the state apparatus. Turkish society is encoded as a homogeneous entity free of contradictory opinions and inequalities across class/gender/race/religion/ethnicities. Such a discourse portrays the state as a neutral (and non-ideological) structure that carefully considers the welfare of each citizen (if and when necessary, even by taking measures against them). In this sense, it is possible to argue that the transforming role of the state from a benign protector (paternal state) to becoming a facilitator and regulator for the market is precisely in line with green economy discourse (Adaman et al. forthcoming). Firstly, the state promotes the belief that environmental problems can be handled without tackling the fetish of economic development. It enables this through regulations that facilitate the actions of the private sector. This legislative-economic framework for the commodification of the commons is part of the green economy, with 'state environmentalism.' Environmental opposition to this branded as purely ideological. The second issue is that the green economy is generous in its creation of voluntary or compulsory carbon trading and ecosystem service payments, sustaining capital accumulation in private hands while benefitting from the coercive power of the state via green 'grabbing' (Fairhead et al. 2012). because of:

Brand (2012) argues that it is impossible for the green economy even to reach its own targets,

- The emphasis on competitiveness;

- The leading role of capitalist market mechanisms and interest-driven technologies;

- Economic development is an indispensable aim;

- Neoliberal elites ensuring their own protection through exercising their favourable power relations.

Madra and Adaman (2014) draw our attention to two basic features of neoliberal thought: the detachment of economic decisions from socio-ecological considerations; and economism (with related technocratisation) that depoliticizes public affairs and democratic control. Hence, it becomes very clear that the institutionalization of the green economy has to do with post-politicization nourished by economism, and with the technocracy attached to it.

Timothy Mitchell's (2002) study was set in Egypt, where he says technocratic regimes respond to two sets of problems: demographic and geographical. These are indeed the reference points for Turkey's environment and development policies and its plans for a green economy. By stressing geographical and demographic imperatives, critical questions are being silenced (such as what kind of country, what kind of city, what kind of livelihood, what kind of development and/or what kind of life does society want?). As Arsel (2012: 79) also highlights, while "how" to do development has always been a matter of concern in the modern history of Turkey, challenging a modernist vision of development with the "why" question has never been on the cards until the Gezi protests. The neoliberal hegemony predominates and avoids asking "why development?" or "what kind of development?" Support for renewable energy should be seen in a similar historical framing, although: 
....alternative energies have been given an ironic cast by decades of 'alternativist' rhetoric contrasting blood-soaked hydrocarbons and apocalypse-threatening nuclear power; but if we remember back to the period of $16^{\text {th }}$ century through most of the $18^{\text {th }}$ century, we should recognize that this was hardly an era of international peace and love. (Caffentzis 2010)

Therefore, when the greenwashing of business-as-usual is not sufficient to respond to the looming crises, a different way of doing things is necessary.

\section{Conclusion}

In the light of this assessment, we argue that a new societal vision should define economic growth as a political, rather than a technical issue. This calls for a redefinition of development. Radically, seeing human societies are part of the ecological system, means the economic presumptions assumed to be unchangeable are actually mere subsets of these systems (Hickel 2016). We have intended to shed light on the hollowed and depoliticized notion of green economy (and, also an authoritarian and unquestionable absolutism) in a time of rapidly expanding social metabolism in Turkey. As an introductory analysis, this critical examination also discloses that we need more information with regard to post-politics and ambiguity of the green economy in Turkey that moves like an elephant in china shop, by bulldozing alternative narratives. The defeat of 'unsustainable' sustainable development notions cannot be reversed by greenwashed technocratic developmentalist policies. Instead an environmental politics with new desires, ideologies and fantasies to counter a hegemony of technical expertise can provide new alternatives to the green economy (Shear 2014).

We argue that such a revelation can only be achieved through augmenting real utopias (Wright 2009) and establishing "spaces of hope" (Harvey 2000) against new enclosures of the commons, by proposing alternative economies in the context of postcapitalist politics (Gibson-Graham 2006; Mason 2015). To put it differently, a transformation is only possible through our common imagination of new narratives for the continuation of a new history. These new narratives can be constructed through the intersection of reformist approaches such as "planned economic recession" (degrowth; Latouche 2009) and the "transition towns" movement (Walker 2011) as well as through meta-narratives such as ecosocialist alternatives (Kovel 2007) and co-revolutionary theory (Harvey 2010). In conclusion we join the calls for constructing alternative languages (Taşkale 2016), by signaling ways to construct these alternative narratives against cynical market environmentalism and countering post-politicization of the environment, in the light of Gezi's signal flare. In building these languages brick by brick, we conclude with the words of Ulus Baker (1996):

De te fabula narratur, they are telling your story [...] the direct translation is not sufficient: What is needed is another narrative replacing it, construction of a brand new meaning, in short, 'telling another story'. We know that many are all eyes and ears there to 'listen to a new story'. Yet, the tongues cannot talk by themselves. Grasping the possibility of different stories- almost infinite in number- can be quite surprising.

\section{References}

Acemoğlu, D. and M. Ucer. 2015. The ups and downs of Turkish growth, 2002-2015: political dynamics, the European Union and the institutional slide (No. w21608). National Bureau of Economic Research.

Adaman, F., B. Akbulut and M. Arsel, 2016. Türkiye'de Kalkınmacılığı Yeniden Okumak: HES'ler ve Değişen Doğa-Toplum İlişkileri, in Aksu, C., S. Erensü and E. Evren (eds.). 2016. Sudan sebepler: türkiye'de neoliberal su-enerji politikaları ve direnişler İstanbul: İletişim Yayınları.

Adaman, F. and M. Arsel (eds.) 2005. Environmentalism in Turkey: between democracy and development? London: Routledge. 
Adaman, F., B. Akbulut, and M. Arsel (eds.). Forthcoming. Neoliberal Turkey and its discontents: economic policy and the environment under Erdogan. London: I.B. Tauris.

Akbulut, B. and F. Adaman. 2013. The unbearable appeal of modernization: The fetish of growth. URL: https://tr.boell.org/de/2014/06/16/unbearable-appeal-modernization-fetish-growth-publikationen (Accessed 16/01/2017)

Akbulut, B. 2014. "A Few Trees" in Gezi Park: resisting the spatial politics of neoliberalism in Turkey. In Sandberg, L.A., A. Bardekjian and S. Butt (eds.). Urban forests, trees and green space: a political ecology perspective. London: Routledge. Pp. 227-241.

Akşam Newspaper 2014. Davutoğlu: Hiç kimse güvende değil, URL: http://www.aksam.com.tr/siyaset/davutoglu-hic-kimse-guvende-degil/haber-353936 (Accessed 16/01/2017)

Aksu, C., S. Erensü and E. Evren (eds.). 2016. Sudan sebepler: türkiye’de neoliberal su-enerji politikalart ve direnişler İstanbul: İletişim Yayınları.

Andreucci, D. and I.M. Radhuber. In press. Limits to "counter-neoliberal" reform: mining expansion and the marginalisation of post-extractivist forces in Evo Morales's Bolivia. Geoforum

Arsel, M. 2012. Environmental studies in Turkey: critical perspectives in a time of neo-liberal developmentalism. The Arab World Geographer 15(1): 72-81. Academia

Atlı, A. 2010. Chinese workers liven up the Turkish coal town, URL: http://bit.ly/1daatCW (Accessed 16/01/2017)

Baker, U. 1996. Marx'ın Bir Çift Sözü Var..., Birikim Dergisi, 84: 20-31. URL: http://bit.ly/1eNKSA2

(Accessed 16/01/2017)

Başkan, A. 2011. Liberalization of Turkey's hydroelectricity sector. In Kibaroğlu, A., W. Schuemann and A. Kramer. Turkey's water policy. Heidelberg: Springer. Pp. 83-91.

Bourdieu, P. 1977. Outline of a theory of practice. Cambridge: Cambridge University Press.

Brand, U. 2012. Beautiful green world: on the myths of a green economy. Luxemburg argumente No. 3. Berlin: Rosa Luxemburg Foundation.

Brockington, D. 2012. A radically conservative vision? The challenge of UNEP's 'Towards a Green Economy'. Development and Change 43(1): 409-422. Researchgate

Brown, E., J. Cloke, D. Gent, P.H. Johnson and C. Hill. 2014. Green growth or ecological commodification: debating the green economy in the global South. Geografiska Annaler: Series B, Human Geography 96(3): 245-259.

Bumpus, A.G. and D.M. Liverman. 2008. Accumulation by decarbonization and the governance of carbon offsets. Economic Geography 84(2): 127-155.

Burak, S.A., E. Dogan and C. Gazioglu. 2004. Impact of urbanization and tourism on coastal environment. Ocean and Coastal Management 47(9): 515-527.

Caffentzis, G. 2010. Everything must change so that everything can remain the same: reflections on Obama's energy plan. In Abramsky, K. (ed.) Sparking a worldwide energy revolution: social struggles in the transition to a post-petrol world. Oakland: AK Press.

Cavanagh, C. and T.A. Benjaminsen. 2017. Political ecology, variegated green economies, and the foreclosure of alternative sustainabilities. Journal of Political Ecology 24: 200-216.

Çelik, N.B. 2010. Siyasal Üzerine. Kitap eleştirisi, kültür ve iletişim 13(2):159-169.

Dombey, D. 2014. Turkey: how Erdoğan did it-and could blow it. Foreign Affairs 93(1): 29-34.

Elektrik Üreticileri Derneği. 2013. Elektrik Üretiminde Dağılım URL: http://bit.ly/1cLQxVE (Accessed 16/01/2017)

Erensü, S. 2015. Abundance and scarcity amidst the crisis of 'modern water'. In Harris, L, J. Goldin and C. Sneddon, (eds.). Contemporary water governance in the Global South: scarcity, marketization and participation. New York: Routledge. 
Fairhead, J., M. Leach and I. Scoones. 2012. Green grabbing: a new appropriation of nature? The Journal of Peasant Studies 39(2): 237-261.

Georgescu-Roegen, N. 1971. The entropy law and the economic process. Cambridge: Harvard University Press.

Gibson-Graham, J.K. 2006. The end of capitalism (as we knew it): a feminist critique of political economy (with a new introduction). University of Minnesota Press.

Goldman, M. 2006. Imperial nature: The World Bank and struggles for social justice in the age of globalization. New Haven: Yale University Press.

Göker, E. 2009. Bârizin Âlimleri: Kanaat Teknisyenleri, Birgün Pazar, 23 Ağustos 2009.

The Invisible $\quad$ Committee $2009 . \quad$ The coming insurrection. https://tarnac9.noblogs.org/gallery/5188/insurrection_english.pdf (Accessed 16/01/2017)

Hamilton, K., M. Sjardin, T. Marcello and G. Xu. 2008. Forging a frontier: state of the voluntary carbon markets 2008. London: Ecosystem Market Place and New Carbon Finance.

Harvey, D. 2000. Spaces of hope. University of Edinburgh Press/University of California Press.

Harvey, D. 2010. The enigma of capital and the crisis of capitalism. Oxford University Press.

Hickel, J. 2016. Clean energy won't save us - only a new economic system can. URL: https://www.theguardian.com/global-development-professionals-network/2016/jul/15/cleanenergy-wont-save-us-economic-system-can (Accessed 16/01/2017)

Hoffman, U. 2011. Some reflection on climate change, green growth illusions and development space. United Nations Conference on Trade and Development Discussions Papers No. 5. Geneva: UNCTAD.

Hopkins, R. 2008. The transition handbook: from oil dependency to local resilience. Vermont: Chelsea Green Publishing.

Hürriyet. 2007. Çevreci yaklaşım ideolojik. URL: http://bit.ly/1ceAooU (Accessed 16/01/2017)

Hürriyet Daily News. 2014. Justice for olive trees blocks coal plant plan. URL: http://www.hurriyetdailynews.com/justice-for-olive-trees-blocks-coal-plantplan.aspx?pageID=238andnID=74190andNewsCatID=340 (Accessed 16/01/2017)

IEN. 2012. Kari-Oca 2 declaration: Indigenous peoples global conference on Rio+20 and Mother Earth. URL: http://www.ienearth.org/kari-oca-2-declaration (Accessed 16/01/2017)

Islar, M. 2012. Privatised hydropower development in Turkey: a case of water grabbing? Water Alternatives 5(2): 376-391.

Jackson, T. 2011. Prosperity without growth: economics for a finite planet. London: Routledge.

Mason, P. 2015. Postcapitalism: a guide to our future. London: Macmillan.

Ministry of Development. 2012. Türkiye'nin Sürdürülebilir Kalkınma Raporu: Geleceği Sahiplenmek 2012. URL: http://www.surdurulebilirkalkinma.gov.tr/wpcontent/uploads/2016/07/1.Gelecegi_Sahiplenmek.pdf (Accessed 16/01/2017)

Kovel, J. 2007. The enemy of nature: the end of capitalism or the end of the world? London: Zed Books.

Kulaklıkaya, M. and R. Nurdun. 2010. Turkey as a new player in development cooperation. Insight Turkey 12(4):131-145.

Kuymulu, M.B. 2013. Reclaiming the right to the city: reflections on the urban uprisings in Turkey. City 17(3): 274-278.

Latouche, S. 2009. Farewell to growth. Cambridge: Polity.

Madra, Y.M. and F. Adaman. 2014. Understanding neoliberalism as economization: the case of the environment. In Y. Atasoy (ed.) Global economic crisis and the politics of diversity. New York: Palgrave Macmillan. Pp. 29-51.

Mert, A. 2016. The trees in Gezi Park: environmental policy as the focus of democratic protests. Journal of Environmental Policy and Planning in press, 1-15.

Milliyet. 2008. Erdoğan: cevre eleştirileri ideolojik. URL: http://bit.ly/1kSEW8U (Accessed 16/01/2017) 
Mouffe, C. 2005. On the political. New York: Routledge.

Muradian, R., M. Walter and J. Martinez-Alier. 2012. Hegemonic transitions and global shifts in social metabolism: implications for resource-rich countries. Global Environmental Change 22(3): 559567.

Mitchell, T. 2002. Rule of experts: Egypt, techno-politics, modernity. University of California Press.

Ministry of Forestry and Water Affairs 2011. Çevre ve Orman Bakanlığı'ndan Belediyelere 103 Adet Katı Atık Toplama Aracı, URL: http://bit.ly/1dMOTPT (Accessed 16/01/2017)

Müller, H. 2014. The dire state of labour rights in Turkey. http://www.turkeyanalyst.org/publications/turkey-analyst-articles/item/346-the-dire-state-of-laborrights-in-turkey.html (Accessed 16/01/2017)

Onaran, Ö. and C. Oyvat. 2016. The political economy of inequality and boom-bust cycles in Turkey: before and after the Great Recession. In Arestis, P. and M. Sawyer (eds.). Emerging economies during and after the Great Recession. Dordrecht: Springer. Pp. 270-309.

Özlüer, M.F., I. Özkaya-Özlüer, T. Şirin and S.N. Odabaşı (eds.). 2012. Bolivya Anayasası: hukuk, demokrasi, özerklik. Ankara: Phoenix Yayınları.

Özsoy, C. 2011. Yeşil Ekonominin Dinamikleri: Yeşil İşler ve Beceriler. Finans Politik and Ekonomik Yorumlar 562(48): 19-32.

Pearce, D.W., A. Markandya and E.B. Barbier (eds.). 1989. Blueprint for a green economy: a report (Vol. 1). London: Earthscan.

Radikal. 2007. Bir de ideolojik olmasalar. URL: http://bit.ly/1h661Wd (Accessed 16/01/2017)

Rockström, J., W. Steffen, K. Noone, Å. Persson, F. Stuart Chapin III, E.F. Lambin, T.M. Lenton, M. Scheffer, C. Folke, H.J. Schellnhuber, B. Nykvist, C.A. de Wit, T. Hughes, S. van der Leeuw, H. Rodhe, S. Sörlin, P.K. Snyder, P.K. R. Costanza, U. Svedin, M. Falkenmark, L. Karlberg, R.W. Corell, V.J. Fabry, J. Hansen, B. Walker, D. Liverman, K. Richardson, P. Crutzen, and J.A. Foley. 2009. A safe operating space for humanity. Nature 461: 472-475.

Sabah. 2013. Bakandan zam açıklaması, URL: http://bit.ly/1hSkpyU (Accessed 16/01/2017)

Schively, C. 2007. Understanding the NIMBY and LULU phenomena: reassessing our knowledge base and informing future research. Journal of Planning Literature 21(3): 255-266.

Scheidel, A. and A.H. Şorman. 2012. Energy transitions and the global land rush: ultimate drivers and persistent consequences. Global Environmental Change 22(3): 588-595.

Shear, B.W. 2014. Making the green economy: politics, desire, and economic possibility. Journal of Political Ecology 21: 193-209.

Spash, C.L. 2011. Terrible economics, ecosystems and banking. Environmental Values 20(2): 141-145.

Swyngedouw, E. 2010. Apocalypse forever? Post-political populism and the spectre of climate change. Theory, Culture and Society 27(2-3): 213-232.

Swyngedouw, E. 2011. Impossible "sustainability" and the post-political condition. In Cerreta, M., G. Concilio and V. Monno (eds.). Making strategies in spatial planning. Heidelberg: Springer. Pp. 185-205.

Swyngedouw, E. 2014. Losing our fear! Facing the Anthro-Obscene, URL: https://entitleblog.org/2014/10/20/losing-our-fear-facing-the-anthro-obscene $\quad$ (Accessed 16/01/2017)

Taşkale, A.R. 2016. Post-politics in context. London: Routledge.

Töngür, Ü. and A.Y. Elveren. 2016. The impact of military spending and income inequality on economic growth in Turkey. Defence and Peace Economics 27(3): 433-452.

Turhan, E. 2014. Soma, Ermenek, Yirca: can anti-coal activists defend coal miners and olive farmers? URL: http://www.jadaliyya.com/pages/index/20304/soma-ermenek-yirca_can-anti-coal-activistsdefend- (Accessed 16/01/2017) 
Turhan, E., S. Cerit Mazlum, Ü. Şahin, A.H. Şorman and A. Cem Gündoğan. 2016. Beyond special circumstances: climate change policy in Turkey 1992-2015. Wiley Interdisciplinary Reviews: Climate Change 7: 448-460. Researchgate

Türk, H.B. 2012. AKP ve Kanaat Teknisyenleri Birikim Dergisi 276: 29-37.

Ulaş, D. 2010. Macahel'de hidroelektrik santrallerin ve ekoturizmin çevreye ve yöre halkına etkileri. Anatolia: Turizm Araştırmaları Dergisi 21(1): 151-158.

Uncu, B. A. 2016. From a conflictual coalition to a social movement? The transformative capacity of the Gezi protests. Southeastern Europe 40(2): 188-216.

UNEP. 2011. Towards a green economy: pathways to sustainable development and poverty eradication. Arendal, Norway: UN Environmental Programme/GRID.

Walker, G. 2011. The role for 'community' in carbon governance. Wiley Interdisciplinary Reviews: Climate Change 2(5): 777-782.

Wanner, T. 2015. The new 'passive revolution' of the green economy and growth discourse: maintaining the 'sustainable development' of neoliberal capitalism. New Political Economy 20(1): 21-41.

Wilson, J. and E. Swyngedouw (eds.). 2014. The post-political and its discontents: spaces of depoliticization, spectres of radical politics. Edinburgh: University of Edinburgh Press.

Wright, E.O. 2009. Envisioning real utopias. New York: Verso.

Žižek, S. 2002. Revolution at the gates - Žižek on Lenin - The 1917 writings. London: Verso. 